\title{
BUTTERFLIES OF CARIRI: PAPILIONOIDEA AND HESPERIOIDEA IN THE SLOPES OF THE CHAPADA DO ARARIPE IN CEARÁ, BRAZIL
}

\author{
Talitha Rochanne Alves Abreu da Costa ${ }^{1}$; Joseph Arimateias D. de C. Sobreira ${ }^{1}$; Karoline Oliveira Mesquita ${ }^{1}$;
} Imeuda Peixoto Furtado ${ }^{1}$

\begin{abstract}
This study aimed at conducting the first species inventory of butterflies in a location in the slopes of the Chapada do Araripe, in Ceará's Cariri region, in the Riacho do Meio Ecological Park. Specimens were collected from June 2009 to July 2010. We collected butterflies actively using insect nets, totaling 96 sampling hours. We collected a total of 236 individuals of 28 species and 5 families [Hesperiidae $(\mathrm{N}=3)$, Lycaenidae $(\mathrm{N}=1)$, Nymphalidae $(\mathrm{N}=15)$, Pieridae $(\mathrm{N}=$ 7) and Riodinidae $(\mathrm{N}=1)$ ]. Nymphalidae was the most diverse family with 16 species and Heliconius erato phyllis (Fabricius) was the most abundant species.
\end{abstract}

Keywords: Chapada do Araripe, inventory, Lepidoptera.

\section{Resumo}

Este estudo teve como objetivo realizar o primeiro inventário de espécies de borboletas na encosta da Chapada do Araripe, na região do Cariri do Ceará, no Riacho do Meio Parque Ecológico. As amostras foram coletadas a partir de junho de 2009 a julho de 2010. Foram coletadas borboletas usando ativamente redes de insetos, totalizando 96 horas de amostragem. Coletados um total de 236 indivíduos de 28 espécies e 5 famílias [Hesperiidae $(\mathrm{N}=3)$, Lycaenidae $(\mathrm{N}=$ 1), Nymphalidae $(\mathrm{N}=15)$, Pieridae $(\mathrm{N}=7)$ e Riodinidae $(\mathrm{N}=1)$ ]. Nymphalidae foi à família mais diversificada, com 16 espécies e Heliconius erato phyllis (Fabricius) foi a espécie mais abundante.

Palavras-chave: Chapada do Araripe, inventário, Lepidoptera.

${ }^{1}$ Universidade Regional do Cariri, Department of Biological Sciences, Rua Coronel Antônio Luiz, 1160, Crato, 63.150-000, Ceará, Brazil. E-mail: litha_nne@yahoo.com.br 


\section{Introduction}

Butterflies represent $13 \%$ of described species in the order Lepidoptera, approximately 19,000. They are divided into two superfamilies: Hesperioidea and Papilionoidea (HEPPNER 1991; BROWN JR.; FREITAS 1999). The superfamily Papilionoidea is subdivided into five families: Lycaenidae, Nymphalidae, Papilionidae, Pieridae and Riodinidae. However, Hesperioidea is represented by the Hesperiidae family only (WAHLBERG et al. 2005).

In Brazil there approximately between 3,130 and 3,300 described species of butterflies (BROWN Jr.; FREITAS 1999). Butterflies are known as one of the most adequate taxonomic groups for environmental assessments

(SPARROW et al. 1994; BROWN Jr.; FREITAS 2000a, b, 2003). Brown Jr. and Freitas (2000a) have used lists of butterfly species from several locations across the Atlantic forest and Cerrado to develop methods to measure biodiversity and its preservation. They reached the conclusion that Hesperiidae diversity is a solid indicator when assessing total fauna wealth. In that sense, in order to carry out environmental assessments the first step is to conduct species inventories, also known as species lists. They provide reliable data bases and may provide reference to studies related to those species; they also contribute to promoting biodiversity and to preserving and monitoring environments. Adult butterfly inventories have been useful tools to plan and manage nature reserves, and for genetic, ecological and taxonomic diversity studies (BROWN Jr.; FREITAS 1999; MOTTA 2002).

Most butterfly diversity inventories in Brazil are being conducted mainly in Rio Grande do Sul (DI MARE et al. 2003; ISERHARD; ROMANOWSKI 2005; MARCHIORI; ROMANOWSKI, 2006a, b; DESSUY; MORAIS 2007), São Paulo (BROWN Jr.; GILFORD 2002; QUEIROZ 2002; CALDAS; ROBBINS 2003; CHAVES et al. 2006; UEHARA-PRADO et al. 2007), Minas Gerais (MOTTA 2002; CALDAS; ROBBINS 2003), Rio de Janeiro (CALDAS; ROBBINS 2003), Distrito Federal (EMERY et al. 2006; MIELKE et al. 2008) and Amazonas (BARLOW et al. 2007). There are few known in the Northeast, we can highlight the work developed by Nobre et al. (2008) in the Camtibau National Park and Paluch et al. (2011) in João Vasconcelos Sobrinho Ecological Park, both in the state of Pernambuco in Chapada Diamantina, Bahia (ZACCA; BRAVO 2012).

There is no substantial information about butterfly species that form the Lepidoptera fauna of Southern Ceará. This study is an attempt to gather knowledge about the diversity of butterflies across the Cariri region in Ceará. It will provide information that will contribute significantly toward gathering knowledge about biodiversity in Brazil and helping its conservation.

\section{Material and Methods}

\section{Area of Study}

The Chapada do Araripe is scattered across 55,000 km² (AUGUSTO; GÓES, 2007). It is located in Southern Ceará, in the border with the States of Pernambuco and Piauí. Its slopes in the state of Ceará are covered by wet woods and it is a priority biodiversity conservation area. In addition to its biological importance, this region has hundreds of water springs that provide water to the entire Cariri region and it also has some of the main rivers in the State of Ceará (AQUASIS, 2009).

This study was conducted in the Riacho do Meio Ecological Park ( $7^{\circ} 22^{\prime} \mathrm{S}$ and $39^{\circ} 20^{\prime} \mathrm{W}$ ), Geosite Arajara, which is close to the Caldas district in the city of Barbalha, State of Ceará. It covers approximately 34.2 ha and its altitude ranges from 690 to 800 meters. Its climate is considered subhumid with average temperatures ranging from $21^{\circ}$ to $25^{\circ} \mathrm{C}$; total rainfall is above $900 \mathrm{~mm}$ and its wet season runs from January to May (URCA; SEBRAE, 2008). The predominant vegetation cover is tree layers of more than 15 meters, similar to the vegetation of the Araripe National Forest - FLONA (FUNCEME, 2006).

The Riacho do Meio Ecological Park is part of Geopark Araripe with Geotope Arajara. Its water resources consist of three natural springs and it is crossed by easy and moderate access tracks. Five sampling points were recorded using an Explorist 100 GPS unit: A) the first one at the park's entrance ( $7^{\circ} 21^{\prime} 53^{\prime \prime} \mathrm{S}-39^{\circ} 19^{\prime} 53^{\prime \prime} \mathrm{W}$ at 757 
meters); B) the second one at the first spring ( $7^{\circ} 22^{\prime} 0^{\prime \prime} \mathrm{S}-39^{\circ} 19^{\prime} 49^{\prime \prime} \mathrm{W}$ at 737 meters); the third one at the second

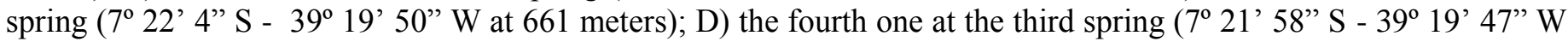
at 761 meters) and the last one E) at Pedra do Morcego (7 $22^{\prime} 0^{\prime \prime} \mathrm{S}-39^{\circ} 19^{\prime} 43^{\prime \prime} \mathrm{W}$ at 682 meters).

\section{Sampling Procedures}

Specimens were actively collected from June 2009 to July 2010 using insect nets from 9:00 AM to 5:00 PM, during butterflies' most active period. We recorded the location, date and time each specimen was collected. They were placed into entomological envelopes and taken to the Invertebrate Zoology Department of URCA - LZI, where they were assembled and dried in a drying sterilizer at approximately $45^{\circ} \mathrm{C}$ and later registered in URCA's entomological collection. The a license for animal collection was granted by Brazilian Institute for the Environment and Renewable Natural Resources - IBAMA (permanent license number 20135);

We used specialized bibliography to identify specimens, such as: Brown Jr. (1992); Brown Jr. and Freitas (1999); Barlow et al. (2007); Canals (2000, 2003); D’Abrera (1984, 1988, 1994, 1995); Fernandez-Díaz (2007); Klimatis (2007); Varga (2000). We used the terminology adopted by Brown Jr. (1992) and Freitas and Brown Jr. (2004), Lamas (2004) and Mielke (2005). André Victor L. Freitas confirmed identifications.

\section{Results and Discussion}

Below there is a list of specimens we found and their respective collection information. We collected a total of 237 specimens from 5 families, 12 subfamilies, 24 genders and 28 species. Heliconius erato phyllis (Fabricius) was the most abundant species with 93 specimens; it was followed by Lycorea halia discreta (Haensch) and Episcada hymenaea hymenaea (Prittwitz) with 25 and 17 specimens, respectively (Table 1). The large number of collected $H$. erato phyllis we found is related to the presence of sources of water; according to Pinheiro et al. (2008), species from the same gender may form small populations in the banks of rivers and streams, close to riparian woods, although not always throughout the year.

Table 1. Number of butterfly species and specimens according to family and subfamily, collected in Riacho do Meio Ecological Park, in the Slopes of the Chapada do Araripe in the Municipality of Barbalha - CE, from June 2009 to July 2010.

\begin{tabular}{lcc}
\hline Taxon & $\mathbf{N}^{\circ}$ of specimens & $\mathbf{N}^{\circ}$ of record \\
\hline PAPILIONOIDEA & & \\
Pieridae (N = 7) & & \\
Coliadinae & 7 & 011002 \\
$\quad$ Anteos clorinde (Godart, [1824]) & 1 & 011011 \\
$\quad$ Eurema albula sinoe (Godart, 1819) & 1 & 011012 \\
$\quad$ Eurema elathea (Cramer, 1777) & 2 & 011021 \\
$\quad$ Phoebis sennae sennae (Cramer, 1777) & 1 & 011023 \\
$\quad$ Pyrisitia leuce leuce (Boisduval, 1836) & 2 & 011024 \\
$\quad$ Pyrisitia nise tenella (Boisduval, 1836) & 3 & 011004 \\
Pierinae & & \\
$\quad$ Ascia monuste orseis (Godart, 1819) & & \\
Nymphalidae (N = 16) & 1 & 011008 \\
Biblidinae & 6 & 011013 \\
$\quad$ Dynamine artemisia artemisia (Fabricius,1793) & & \\
$\quad$ Hamadryas feronia (Linnaeus, 1758) & & \\
\hline
\end{tabular}




\begin{tabular}{|c|c|c|}
\hline Hamadryas februa februa (Hübner, [1823]) & 2 & 011014 \\
\hline \multicolumn{3}{|l|}{ Charaxinae } \\
\hline Archaeprepona demophon thalpius (Hübner, [1814]) & 3 & 011003 \\
\hline \multicolumn{3}{|l|}{ Danainae } \\
\hline Lycorea halia discreta Haensch, 1909 & 28 & 011018 \\
\hline \multicolumn{3}{|l|}{ Heliconiinae } \\
\hline Dryas iulia alcionea (Cramer, 1779) & 5 & 011007 \\
\hline Euptoieta hegesia meridiania Stichel, 1938 & 2 & 011010 \\
\hline Heliconius erato phyllis (Fabricius, 1775) & 93 & 011015 \\
\hline Heliconius ethilla flavomaculatus Weymer, 1894 & 2 & 011016 \\
\hline \multicolumn{3}{|l|}{ Ithomiinae } \\
\hline Dircenna dero celtina Burmeister, 1878 & 14 & 011006 \\
\hline Episcada hymenaea hymenaea (Prittwitz, 1865) & 17 & 011009 \\
\hline Methona singularis (Staudinger, [1884]) & 7 & 011019 \\
\hline \multicolumn{3}{|l|}{ Nymphalinae } \\
\hline Junonia genoveva hilaris C. \& R. Felder, [1867] & 1 & 011017 \\
\hline Ortilia ithra (Kirby, 1900) & 3 & 011020 \\
\hline Siproeta stelenes meridionalis (Fruhstorfer, 1909) & 7 & 011025 \\
\hline \multicolumn{3}{|l|}{ Satyrinae } \\
\hline Taygetis laches marginata Staudinger, 1887 & 11 & 011026 \\
\hline \multicolumn{3}{|l|}{ Riodinidae (N=1) } \\
\hline \multicolumn{3}{|l|}{ Riodininae } \\
\hline Melanis sp. & 1 & 011028 \\
\hline \multicolumn{3}{|l|}{ Lycaenidae (N=1) } \\
\hline \multicolumn{3}{|l|}{ Theclinae } \\
\hline Pseudolycaena marsyas (Linnaeus, 1758) & 1 & 011022 \\
\hline \multicolumn{3}{|l|}{ HESPERIOIDEA } \\
\hline \multicolumn{3}{|l|}{ Hesperiidae $(\mathrm{N}=3)$} \\
\hline \multicolumn{3}{|l|}{ Pyrginae } \\
\hline Aguna asander asander (Hewitson, 1867) & 3 & 011001 \\
\hline Astraptes fulgerator fulgerator (Walch, 1775) & 4 & 011005 \\
\hline Urbanus dorantes dorantes (Stoll, $[1790])$ & 8 & 011027 \\
\hline TOTAL & 236 & \\
\hline
\end{tabular}

The Nymphalidae family was the most diverse one with 16 species. Lycaenidae and Riodinidae families were not very diverse in this study and we did not find any specimens of the Papilionidae family. In studies conducted in the South, Southeast (SACKIS; MORAIS 2008) and Northeast (NOBRE et al. 2008) regions in Brazil the Nymphalidae family was also the most diverse. However, the Lycaenidae family was the third most diverse in a study conducted in the Catimbau National Park in semi-arid Northeast, in the State of Pernambuco (NOBRE et al. 2008).

We did not find any species of the Papilionidae family in this study; this is probably due to the fact that species of that family are associated with another type of habitat. According to Brown Jr. (1992) and Schwartz and Di Mare (2001), species of that family can usually be found in places disrupted by humans or in urban perimeters. This can also be associated with the fact that papilionidae are considered difficult to sample; this has been confirmed by Brown Jr. (1992) and Brown Jr. and Freitas (1999).

We observed a greater number of butterflies in the months of August (49), September (34) and October (34) and a smaller number in the months of February (0) and April (2) 2010. The fact that there were no butterflies in the months of August, September and October 2009 can be explained by the occurrence of precipitation postseason above the historical average of Ceará in 2009 (FUNCEME, 2009). The rainy season in the region, which extends from 
January to May, made it impossible for researchers to collect insects in February 2010. This accounts for lack of samples in that month, as well as a small number of samples in April 2010.

According to Vieira (2009), rainy days can be less productive than sunny days and this may be a factor that influences variation. There are also species that can only be found in certain times of the year, while others only appear during dry or rainy seasons, and others show no pattern at all. Because there is no prior data on this, it is necessary to conduct further insect collection in order to better understand butterfly biodiversity in this biome. However, data from this study are the single source of information about butterfly composition in the Chapada do Araripe, an area which is considered crucial for biodiversity conservation. Therefore, it is necessary to publish such data.

\section{Acknowledgements}

We would like to thank Dr. André Victor L. Freitas for confirming specimens. We would also like to thank the following: CNPq for awarding a Scientific Initiation Grant - PIBIC (File \# 109863/2009-7); the Secretaries for the Environment and Water Resources in the Municipality of Barbalha, Marcos Maciel Torres and Polyana Silva Coimbra for allowing us to collect animals in the Riacho do Meio Ecological Park.

\section{Literature Cited}

AQUASIS. Associação de Pesquisa e Preservação de Ecossistemas Aquáticos -. Refúgio de Vida Silvestre do Soldadinho-do-araripe. Available in: < http://www.aquasis.org/projeto>. Captured on: February 3, 2009.

AUGUSTO, L. G. DA S.; GÓES, L. Compreensões integradas para a vigilância da saúde em ambiente de floresta: o caso da Chapada do Araripe, Ceará, Brasil. Cadernos de Saúde Pública, Rio de Janeiro, 23 Sup. v. 4, p. 549-558, 2007.

BARLOW, J. et al. The value of primary, secondary and plantation forests for Amazonian birds. Biological Conservation, v.136, p.212-231, 2007.

BROWN JR., K. S. JR. Borboletas da Serra do Japi: diversidade, habitats, recursos alimentares e variação temporal. Inl: DE MORELLATO, L. P. História Natural da Serra do Japi: ecologia e preservação de uma área florestal no sudeste do Brasil. Campinas: Editora da Unicamp, 1992. p. 142-187.

BROWN JR., K. S.; FREITAS, A. V. L. Lepidoptera. Biodiversidade do Estado de São Paulo, Brasil. Inl: DE BRANDÃO, C. R. F.; CAMCELLO, E.M. Invertebrados terrestres. São Paulo: FAPESP, 1999. p. 227-243

BROWN JR., K. S.; FREITAS, A. V. L. Atlantic Forest butterflies indicators for landscape conservation. Biotropica, v. 32, p. 934-956, 2000a.

BROWN JR., K. S.; FREITAS, A. V. L. Diversidade de Lepidoptera em Santa Teresa, Espírito Santo. Boletim do Museu de Biologia Mello Leitão, v. 11, n. 12, p. 71-116, 2000 b.

BROWN JR., K. S.; FREITAS, A. V. L. Butterfly communities of urban Forest fragments in Campinas, São Paulo, Brazil: Structure, instability, environmental correlates, and conservation. Journal of Insect Conservation, v. 6, p. 217 231, 2003. 
BROWN JR., K. S.; GILFFORD, D. R. Lepidoptera in the cerrado landscape and the conservation of the vegetacion, soil, and topographical mosaics. Inl: DE OLIVEIRA, P.S.; MARQUIS, R, J. The cerrados of Brazil: ecology and natural history of a neotropical savanna. New York: Columbia Univerty Press, 2002. p. 201-217.

CALDAS, A.; ROBBINS, R. K. Modifield Pollard transeds for assessing tropical butterfly abundance and diversity. Biological Conservation, v. 100, p. 211-219, 2003.

CANALS, G. R. Butterflies of Buenos Aires. Buenos Aires, L.O.L.A., 2000.

CANALS, G. R. Mariposas de Misiones. Buenos Aires, L.O.L.A., 2003.

CHAVES, G. W.; PATTO, C. E. G.; BENSON, W. W. Complex Non-Aerial Contests in the Lekking Butterfly Charis cadytis (Riodinidae). Journal of Insect Behavior, v. 19, n. 2, p. 179-196, 2006.

D’ ABRERA, B. Butterflies of South America. Vitoria, Hill House, 1984.

D'ABRERA, B. Butterflies of the Neotropical Region. Part V. Nymphalidae (Conc.) \& Satyridae. Victoria, Hill House, 1988.

D’ ABRERA, B. Butterflies of the Neotropical Region. Part VI. Riodinidae. Hill House, Victoria, 1994.

D’ABRERA, B. Butterflies of the Neotropical Region. Part. VII. Lycaenidae. Victoria, Hill House, 1995.

DESSUY, M. B.; MORAIS, A. B. B. Diversidade de borboletas (Lepidoptera, Papillionoidea e Hesperioidea) em fragmentos de Floresta Estacional Decidual em Santa Maria, Rio Grande do Sul, Brasil. Revista Brasileira de Zoologia, v. 24, n. 1, p. 108-120, 2007.

DI MARE, R. A.; TESTON, J. A.; CORSEUIL, E. Espécies de Adelpha Hübner (1819) (Lepidoptera, Nymphalidae, Limennitidinae) ocorrentes no Rio Grande do Sul, Brasil. Revista Brasileira de Entomologia, v. 47, n. 1, p. 75-79, 2003.

EMERY, E. O.; BROWN JR., K. S.; PINHEIRO, C. E. G. As borboletas (Lepidoptera, Papilionoidea) do Distrito Federal, Brasília. Revista Brasileira de Entomologia, v. 50, p. 85-92, 2006.

FERNÁNDEZ DÍAZ, C. I. Misiones mariposas/ butterflies/ borboletas. Buenos Aires: Golden Company, 2007.

FREITAS, A. V. L.; BROWN JR., K. S. Phylogeny of the Nymphalidae (Lepidoptera). Systematic Biology, v. 53, n. 3, p. 1-25, 2004.

FUNCEME. FUNDAÇÃO CEARENSE DE METEOROLOGIA E RECURSOS HÍDRICOS. Zoneamento geoambiental do estado do Ceará: parte II meso região do sul cearense. Fortaleza, 2006.

HEPPNER, J. B. Faunal regions and the diversity of Lepidoptera. Tropical Lepidoptera, v. 2, n. 1, p. 1-85, 1991.

ISERHARD, C. A. A.; ROMANOWSKI, H. P. Lista de espécies de borboletas (Lepidoptera, Papilionoidea e Hesperoidea) da região do rio Maquiné, Rio Grande do Sul, Brasil. Revista Brasileira de Zoologia, v. 21, n. 3, p. 649$662,2005$.

KLIMATIS, J. F. 100 mariposas argentinas. Buenos Aires, 2007. 
LAMAS, G. Checklist: Hesperioidea - Papilionoidea. Inl: DE HEPPNER, J. B. Atlas of Neotropical Lepidoptera 5A. Gainesville: Association for Tropical Lepidoptera, 2004. p. XXXVI + 439.

MARCHIORI, M. O; ROMANOWSKI, H. P. Borboletas (Lepidoptera, Papilionoidea e Hesperioidea) do Parque Estadual do Espinilho e entorno, Rio Grande do Sul, Brasil. Revista Brasileira de Zoologia, v. 23, n. 4, p. 1029-1037, 2006a.

MARCHIORI, M. O.; ROMANOWSKI, H. P. Species composition and diel variation of a butterfly taxocenose (Lepidoptera, Papilionoidea, Hesperioidea) in a resting forest et Itapuã State Park, Rio Grande do Sul, Brasil. Revista Brasileira de Zoologia, v. 23, n. 2, p. 443-454, 2006 b.

MIELKE, O. H. Catalogue of the American Hesperioidea: Hesperiidae (Lepidoptera). Complementary and supplementary parts to the checklist of the Neotropical region. Hesperioidea: Hesperiidae: Pyrrhopyginae. Curitiba. Sociedade Brasileira de Zoologia, v. 1. 125p, 2005.

MIELKE, O. H.; EMERY, E. O.; PINHEIRO, C. E. As borboletas Hesperiidae (Lepidoptera, Hesperioidea) do Distrito Federal. Revista Brasileira de Entomologia, v. 52, n. 2, p. 283-288, 2008.

MOTTA, P. C. Butterflies from the Uberlândia region, central Brazil: species list and biological comments. Brazilian Journal of Biology, v. 62, n. 1, p. 151-163, 2002.

NOBRE, C. E. B.; SCHLINDWEIN, C.; MIELKE, O. H. The butterflies (Lepidoptera: Papilionoidea and Hesperioidea) of the Catimbau National Park, Pernambuco, Brazil. Zootaxa, n.1751, p. 35-45, 2008.

PINHEIRO, C. E. G. et al. As borboletas (Lepidoptera, Papilionoidea) do Campus Universitário Darcy Ribeiro (Distrito Federal, Brasil). Biota Neotropica, v. 8, no. 4, 2008.

PALUCH, M. et al. Butterflies (Lepidoptera: Papilionoidea and Hesperioidea) of the Parque Ecológico João Vasconcelos Sobrinho, Caruaru, Pernambuco, Brazil. Biota Neotropica, v.11, n.4, p. 229-238, 2011.

QUEIROZ, J. M. Host plant use among closely related Anaea butterfly species (Lepidoptera, Nymphalidae, Charaxinae). Brazilian Journal of Biology, v.62, n. 4A, p. 657-663, 2002.

SCHAWARTZ, G.; DI MARE, R. A. Diversidade de quinze espécies de borboletas (Lepidoptera, Papilionidae) em sete comunidades de Santa Maria, RS. Ciência Rural, v. 31, p. 51-61, 2001.

SACKIS, G. D.; MORAIS, A. B. B. Borboletas (Lepidoptera: Hesperioidea e Papilionoidea) do campus da Universidade Federal de Santa Maria, Santa Maria, Rio Grande do Sul. Biota Neotropica, v. 8. n.1, 2008.

SPARROW, H. R. et al. Techniques and guidelines for monitoring Neotropical butterflies. Conservation Biology, v. 8, p. 800-809, 1994.

UEHARA-PRADO, M.; BROWN JR., K. S.; FREITAS, A. V. L. Species richness, composition and abundance of fruit-feeding butterflies in the Brazilian Atlantic Forest: comparison between a fragmented and a continuous landscape. Global Ecology and Biogeography, v.16, p. 43-54, 2007.

URCA; SEBRAE; ONG - CANDEEIRO DAS TRILHAS. Diagnóstico Ambiental Parque Ecológico do Riacho do Meio. Available in: <http://candeeirodastrilhas.wordpress.com/2008/04/05/diagnostico-de-impacto-ambientalparque-ecologico-do-riacho-do-meio/>.Captured on February 3, 2009.

VARGA, A. E. 2000. Mariposas Argentinas, v. 1, 148 p. 
VIEIRA, R. S. Borboletas frugívoras da Reserva Florestal Adolpho Ducke. Available in: < http://ppbio.inpa.gov.br/sites/default/files/Guia_borboletas.pdf>. Captured on: February 03, 2009.

WAHLBERG, N. et al. Synergistic effects of combining morphological and molecular data in resolving the phylogeny of butterflies and skippers. Journal of the Royal Society Biology, v. 272, p. 1577-1586, 2005.

ZACCA, T.; BRAVO, F. Butterflies (Lepidoptera: Papilionoidea and Hesperioidea) of the northern portion of the Chapada Diamantina, Bahia, Brazil. Biota Neotropica. v.12, n.2, p. 117-126, 2012. 